\title{
Disparitas Gender dalam Penggunaan Istilah pada Kosakata Budaya Masyarakat Melayujambi di Provinsi Jambi
}

\author{
Ernanda $^{1 *}$, Dwi Rahariyoso ${ }^{2)}$, Julisah Izar ${ }^{3)}$ \\ ernanda@unja.ac.id ${ }^{1)}$, jeketlusuh@gmail.com ${ }^{2)}$, julisahizar@unja.ac.id ${ }^{3)}$ \\ Universitas Jambi, Jambi, Indonesia
}

\begin{abstract}
Abstrak. Penelitian ini bertujuan untuk mengungkap konstruksi linguistik dan penggunaan istilah yang memuat disparitas gender yang telah menyatu dengan sistem kognitif, budaya, dan menjadi kebiasaan yang diekspresikan di dalam masyarakat. Metode dalam penelitian ini adalah metode deskriptif kualitatif dengan menggunakan pendekatan etnolinguistik. Adapun metode pengumpulan data dalam penelitian ini dengan menggunakan wawancara dan pengamatan. Metode wawancara digunakan untuk meninjau kembali apakah data bahasa yang berupa kosakata budaya berupa istilah dalam masyarakat MelayuJambi yang dirujuk pada Kamus MelayuJambi benar adanya. Sedangkan, metode pengamatan digunakan untuk melihat apakah istilah pada kosakata budaya tersebut masih berfungsi dan digunakan dalam tindak komunikasi serta dalam aktivitas budaya di tengah masyarakat MelayuJambi. Adapun hasil dalam penelitian ini menunjukkan adanya 20 istilah dalam kamus Kamus MelayuJambi yang mengandung disparitas gender yang benar adanya dan kosakata dengan jenis-jenis istilah tersebut masih populer dan masih digunakan di kalangan masyarakat Jambi.
\end{abstract}

Kata kunci: disparitas gender, penggunaan istilah, Masyarakat MelayuJambi.

\section{Pendahuluan}

Kebudayaan merupakan manifestasi sosiologis dalam masyarakat. Dimensi kebudayaan menghasilkan suatu tatanan yang diyakini sekaligus disepakati oleh anggota masyarakatnya. Seiring dengan kurun waktu dan perubahan zaman, kebudayaan pun terus mengalami negosiasi dan penyesuaian. Indonesia sebagai salah satu negara kepulauan dengan lebih dari 700 suku bangsa, secara nasional memiliki beragam latar belakang serta corak kebudayaan. Setiap etnis dan suku bangsa memiliki karakteristiknya masing-masing, melalui hasil kebudayaan, seperti, pengetahuan, artefak, keyakinan, seni, sistem sosial, teknologi, hingga bahasa. Keunikan ini tersebar dari wilayah Aceh hingga Papua.

Dalam perkembangan kebudayaan nusantara dan nasional, Indonesia dikenal masyarakat yang berbasis patriarkat sebagai ciri fundamentalnya. Patriarkat dalam hal ini secara sederhana bisa diterjemahkan sebagai suatu model kebudayaan yang cenderung mengacu pada posisi kaum laki-laki yang menjadi pusat (dominan). 'Pusat' dalam artian, persepsi atau ukuran dalam menentukan kadar konstruksional kebudayaan atau pranata sistem sosial dengan pandangan kaum laki-laki.

Sistem patriarkat juga menjadi karakteristik dalam kebudayaan Melayu. Masyarakat Melayudalam perkembangan kebudayaannya mengalami transformasi seiring dengan masuknya agama-agama, mulai dari era Hindu hingga Islam. Sejarah mencatat bahwa wilayah Jambi, terutama di sekitar Sungai Batanghari, diakui sebagai pusat kerajaan pre-Islamic Melayu(Gin, 2004). Dalam kenyataan tersebut, sistem kebudayaan yang ada di Provinsi Jambi secara umum memiliki karakteristik patriarkat. 
Sistem patriarkat ini memengaruhi peranti dan sarana kebudayaan yang ada, mulai dari klasifikasi dan pemilahan ruang bagi laki-laki dan perempuan, peran serta keterlibatan laki-laki dan perempuan (sistem tata norma), profesi, pendidikan, arsitektur, pakaian, hingga ke domain bahasa.

Bahasa memegang peranan penting dalam sistem patriarki, tidak sekadar sebagai fungsi komunikasi melainkan juga mengarah pada munculnya dominasi serta hierarki (kesenjangan) antara posisi laki-laki dengan perempuan di hadapan kebudayaan. Bahasa dengan demikian merupakan sarana yang mengonstruksi kesadaran serta menunjukkan hadirnya "kekuasaan" atas suatu kelompok kepentingan, dalam hal ini kepentingan patriarkat.

Istilah dan konsep gender dikenalkan pertama kali oleh Margaret Mead, seorang pakar antropologi dari Amerika (Koentjaraningrat dalam Faraz, 2013). Dalam penelitiannya Ia memperoleh kesimpulan bahwa perbedaan yang hadir antara laki-laki dan perempuan dalam perilaku serta kepribadiannya tidak bersifat universal dan alamiah. Selain itu, Showalter (1983) berpendapat bahwa gender adalah kategorisasi yang membedakan posisi antara laki-laki dan perempuan berdasarkan konstruksi sosial budaya.

Selain itu, istilah gender juga dirumuskan dalam Ensiklopedia Kajian Perempuan (Women's Studies Encyclopedia), yaitu gender merupakan konsep kultural yang hadir bagi lakilaki dan perempuan dalam masyarakat yang berfungsi membedakan karakteristik emosional, mentalitas, perilaku, serta peran mereka (Mulia, 2004).

Fakih (2013) menyatakan bahwa ketidakadilan gender seolah sudah menjadi stereotipe dalam masyarakat karena kebiasaan dan klasifikasi peran yang terjadi dalam proses yang lama. Hal-hal yang terkait peran seseorang dalam aktivitas domestik (rumah tangga), semisal mengasuh anak, mengurus urusan rumah tangga seringkali diasosiasikan sebagai fitrah perempuan yang feminin.

Katubi (2004) mengemukakan tiga alasan mengapa bahasa dijadikan sebagai objek penelitian dalam kajian gender. Pertama, orientasi penelitian gender adalah membongkar disparitas gender yang terjadi melalui aspek-aspek budaya dalam masyarakat. Asumsinya adalah bahasa dan budaya memiliki keterkaitan erat, baik itu relasional maupun subrelasional.

Adapun penelitian terdahulu dilakukan oleh Iswah Adriana (2012). Penelitian tersebut memaparkan gambaran tentang fenomena bahasa sebagai media komunikasi yang digunakan sebagai status sosial dan mampu mempertegas diskriminasi gender antara laki-laki dengan perempuan. Melalui kajian sosiolinguistik, Adriana mengupas perbedaan gender yang didasari oleh isu kekuasaan laki-laki terhadap perempuan.

Penelitian kedua, yang dilakukan oleh Prasetyo Adi Wisnu Wibowo (2012) menjelaskan tentang karakteristik dan gaya berbahasa yang dipengaruhi oleh gender karena aspek pembeda kebahasaan tidak selalu ada dalam bahasa, melainkan juga dipengaruhi oleh jenis kelamin.

Penelitian ketiga, yang dilakukan oleh Nuril Huda, Aliyah A. Rasyid, Pujiati Suyata, dan Sumarno (2013) menggunakan model penelitian dari kerangka Borg dan Gall. Ada sepuluh tahapan yang ditawarkan, yaitu studi awal, perencanaan tipe, pengembangan tipe awal, uji coba tipe awal, revisi tipe awal, uji coba lingkup terbatas, revisi uji coba lingkup terbatas, uji tipe akhir, revisi, dan terakhir adalah penerapan dan hasil. Hal yang menarik dari model penelitian ini adalah adanya penggabungan dua teknik analisis gender model Harvard dan model Mosser yang 
dicampurkan sehingga disingkat menjadi model analisis HARMOS untuk melengkapi teknik analisis gender yang digunakan. Melalui pendekatan kualitatif, teknik analisis datanya berpijak pada analisis kualitatif fenomenologi.

Dalam Kamus Kosakata Budaya Jambi yang disusun oleh Kantor Bahasa Jambi edisi kedua (2015), ditemukan beberapa gejala dan fenomena hadirnya disparitas gender dalam bahasa. Gejala dan fenomena tersebut menegaskan hadirnya suatu konstruksi bahasa yang memosisikan kaum (jenis kelamin) laki-laki lebih superior dan cenderung lebih hegemonik dibanding kaum perempuan.

Kondisi inilah yang menjadi realitas yang menarik untuk ditelaah lebih lanjut dalam kaitannya dengan persoalan gender. Tidak menutup kemungkinan bahwa implikasi dari realitas tersebut melahirkan persoalan ideologis dalam masyarakat secara umum, yaitu ketidakadilan gender. Wacana ketidakadilan gender inilah yang akan diidentifikasi dan dianalisis dalam kaitannya dengan bahasa secara sosial maupun secara etnik. Pola-pola kultural yang hadir dan terekspresi melalui bahasa akan dijadikan sebagai data untuk dikaji dengan mempertimbangkan peran serta posisi gender secara kritis. Apakah di dalam kelompok masyarakat tersebut ditemukan bahasa istilah yang menjadi sarana dan praktik terjadinya ketidakadilan gender (dominasi maskulin) dalam berbagai bidang kebudayaan.

\section{Metode}

Metode dalam penelitian ini adalah metode deskritif kualitatif dengan menggunakan pendekatan etnolinguistik. Pendekatan etnolinguistik menurut Muhajir (1990:163) berupaya mencari dan menata secara sistematis hasil observasi, wawancara dan lainnya untuk menjawab pertanyaan penelitian. Etnografis diasumsikan linear dengan etnolinguistik dalam proporsinya mengolah data yang diperoleh dari deskripsi kosakata budaya suatu masyarakat tertentu. Identifikasi kerangka budaya inilah yang menjadi relevansi dalam kaitannya menjelaskan aspek disparitas gender dalam suatu sistem kultural masyarakat.

Data penelitian ini adalah penggunaan istilah yang berhubungan dengan disparitas gender. Data linguistik berupa kosakata budaya Jambi yang dikhususkan ke dalam bentuk istilah dalam masyarakat yang dirujuk dalam Kamus Kosakata Budaya Jambi yang nantinya akan ditelusuri secara mendalam dengan melakukan wawancara langsung dengan masyarakat yang mempunyai kosakata tersebut . Selain itu, data etnografi yang meliputi pola perilaku, nilai moral dan kultural masyarakat pada situasi sosial tertentu terkait dengan disparitas gender. Sumber data dalam penelitian ini adalah masyarakat MelayuJambi yang memiliki kosakata yang mengandung unsur disparitas yang dirujuk pada Kamus Kosakata Budaya Jambi.

Adapun teknik pengumpulan datanya menggunakan metode wawancara dan pengamatan. Metode wawancara digunakan untuk meninjau kembali apakah data bahasa berupa istilah dalam masyarakat MelayuJambi yang dirujuk pada Kamus MelayuJambi benar adanya. Jawaban informan akan dicatat dan proses wawancara ini direkam secara audio visual. Sedangkan, metode pengamatan digunakan untuk melihat apakah istilah kosakata budaya tersebut masih berfungsi dan digunakan dalam tindak komunikasi serta dalam aktivitas budaya di tengah masyarakatnya atau tidak. 


\section{Hasil dan Pembahasan}

\section{Hasil}

Dalam Kamus Kosakata Budaya Jambi yang disusun oleh Kantor Bahasa Jambi edisi kedua (2015) ditemukan beberapa gejala dan fenomena hadirnya disparitas gender dalam penggunaan istilah. Gejala dan fenomena tersebut menegaskan hadirnya suatu konstruksi bahasa yang memosisikan kaum (jenis kelamin) laki-laki memiliki kemungkinan superior dan cenderung hegemonik dibanding kaum perempuan. Kecenderungan ini dapat diidentifikasi dari peranti dan sarana bahasa dalam kebudayaan yang ada, mulai dari klasifikasi dan pemilahan ruang bagi lakilaki (pria) dan perempuan (wanita) perempuan, peran serta keterlibatan laki-laki dan perempuan (dalam sistem tata norma), profesi, pendidikan, arsitektur, pakaian, hingga ke bahasa. Kondisi tersebut menjadi realitas yang menarik untuk ditelaah lebih lanjut dalam kaitannya dengan persoalan gender. Tidak menutup kemungkinan bahwa implikasi dari realitas tersebut melahirkan persoalan ideologis dalam masyarakat secara umum, yaitu persoalan gender. Gender sendiri, secara kultural, masih diasumsikan sebagai klasifikasi jenis kelamin laki-laki dan perempuan. Stereotip atas pemahaman ini menjadi suatu permasalahan yang kompleks, terutama kaitannya dalam relasi laki-laki dan perempuan dalam sistem kebudayaan.

Kosakata budaya penggunaan istilah dalam kamus tersebut menunjukkan bahwa di beberapa (bahkan mayoritas) wilayah kabupaten yang ada di Provinsi Jambi secara umum memiliki karakteristik terjadinya gejala disparitas gender dalam bahasa dan kebudayaannya. Melalui asumsi tersebut, sangat mungkin untuk ditemukan fenomena-fenomena kebudayaan yang memiliki kecenderungan bias gender, termasuk di dalamnya penggunaan bahasa. Dalam hasil penelitian ini akan disajikan bentuk kosakata MelayuJambi pada penggunaan istilah dalam Kamus Kosakata Budaya Jambi terbitan Kantor Bahasa Jambi tahun 2015. Jenis kosakata istilah yang ditemukan tersebut kemudian dianalisis berdasarkan penggunaannya.

Tabel Penggunaan istilah budaya dalam Kamus Kosakata Budaya Jambi

\begin{tabular}{|c|c|c|c|c|}
\hline No & Kosakata & Jenis & Arti & Keterangan \\
\hline 1. & Asabah & Istilah & Saudara laki-laki ayah & $\begin{array}{l}\text { Dominasi dan superioritas laki- } \\
\text { laki (istilah untuk saudara } \\
\text { perempuan Ayah dan atau dr } \\
\text { pihak ibu tidak ada) }\end{array}$ \\
\hline 2. & Cinge & Istilah & $\begin{array}{l}\text { Pakaian adat laki-laki berupa } \\
\text { celana panjang terbuat dari kain } \\
\text { beledu warna merah, bagian } \\
\text { pinggang diberi tali, bersulam } \\
\text { benang emas, dengan motif bunga } \\
\text { tagapo, melati, dan pucuk rebung }\end{array}$ & $\begin{array}{l}\text { Detail pakaian laki-laki (dalam } \\
\text { kamus tidak ditemukan detail } \\
\text { serupa untuk pakaian perempuan) }\end{array}$ \\
\hline 3. & $\begin{array}{l}\text { Datuk sutan } \\
\text { pati }\end{array}$ & Istilah & $\begin{array}{l}\text { Sebutan untuk pohon besar yg } \\
\text { digunakan untuk menambat jerat } \\
\text { rusa }\end{array}$ & $\begin{array}{l}\text { Superioritas laki-laki (metafora } \\
\text { "datuk" sebagai kekuatan } \\
\text { maskulin laki-laki) }\end{array}$ \\
\hline 4. & $\begin{array}{l}\text { Duduk } \\
\text { batanyo }\end{array}$ & Istilah & $\begin{array}{l}\text { Adat meminang, utusan keluarga } \\
\text { pihak laki-laki berkunjung ke } \\
\text { rumah pihak keluarga perempuan } \\
\text { untuk menanyakan apakah anak } \\
\text { perempuan mereka sudah ada yg } \\
\text { punya }\end{array}$ & $\begin{array}{l}\text { Subordinasi perempuan } \\
\text { (meminang seolah diasumsikan } \\
\text { sebagai transaksi kepemilikan dr } \\
\text { perspektif laki-laki) }\end{array}$ \\
\hline
\end{tabular}




$\begin{array}{llr}\text { 5. } & \text { Getek } & \text { Istilah } \\ \text { 6. } & \text { Jok } & \text { Istilah } \\ \text { 7. } & \text { Kulub/kulup } & \text { Istilah }\end{array}$

8. Lacak

Istilah

9. Lenjeh

Istilah

10. Mangku

Istilah

11. Nambang

Istilah

12. Pakcik

Istilah

13. Pakmuk

Istilah

14. Pakte

Istilah

15. Putri kandis

Istilah

16. Sundai

Istilah

$17 \quad$ Sundang

Istilah

18. Tengganai

Istilah

19. Tuo tengganai Istilah
Lincah dan genit (terutama anak perempuan); banyak gaya Panggilan untuk laki-laki muda yang masih bujangan

Panggilan untuk anak yg belum dikhitan;

panggilan sayang untuk orang yg sudah dewasa

Bagian pakaian adat laki-laki, sejenis tutup kepala terbuat dr kain beledu berwarna merah bersulam benang emas, bermotif daun, tangkai, dan bunga, bagian depan berbentuk runcing ke atas dan bagian belakang datar.

Lincah dan genit (terutama anak perempuan); banyak gaya; getek 1. Pemimpin dusun yang berperan sebagai sekretaris dan wakil penghulu;

2. pemimpin adat yang berada $\mathrm{d} i$ bawah Depati (Kubu)

Menjual diri untuk memenuhi kebutuhan ekonomi

Kata sapaan yg digunakan untuk menyapa saudara laki-laki ayah dan ibu yg berperawakan kecil Kata sapaan yg digunakan untuk menyapa saudara laki-laki ayah dan ibu yg berperawakan gemuk Kata sapaan yg digunakan untuk menyapa saudara laki-laki ayah dan ibu yg berkulit putih

Kue yg terbuat dr 20 butir telur, air pandan, tepung, gula, margarin, yg dimasak dng cara dipanggang lapis demi lapis

Kekuatan gaib yg dilakukan dng membaca mantra atau guna-guna untuk memikat perempuan

Senjata genggam tradisional yg terbuat dr besi yg ditempa pipih, mempunyai dua mata yg berbentuk meruncing ke ujung, tangkai terbuat dr kayu yang berbentuk kepala burung berparuh panjang, berfungsi sbg pelengkap pakaian dl upacara adat dan dipakai oleh hulu balang

Saudara laki-laki

Saudara laki-laki dr pihak istri dan pihak suami dl sekumpulan keluarga yg bertugas mengarahkan dan menyelesaikan masalah yg
Subordinasi perempuan (peyoratif)

Diskriminasi (Untuk perempuan muda tidak ada)

Diskriminasi (konteks panggilan untuk laki-laki)

Superioritas laki-laki (pakaian dg fungsi serupa yang dikenakan untuk perempuan tidak disebutkan)

Subordinasi perempuan (peyoratif)

Superioritas laki-laki (pemimpin)

\section{Objektivikasi perempuan}

Superioritas laki-laki, dominasi (untuk perempuan tidak disebutkan)

Superioritas laki-laki, dominasi (untuk perempuan tidak disebutkan)

Superioritas laki-laki, dominasi (untuk perempuan tidak disebutkan)

Objektivikasi perempuan (stereotipe istilah "putri" (perempuan) sbg makanan).

Objektivikasi perempuan (mantra untuk perempuan tidak ada/tidak disebutkan)

Superioritas \& dominasi laki-laki (konteks hulu balang adalah mereka yg berjenis kelamin lakilaki)

Superioritas Laki-laki \& diskriminasi (istilah untuk perempuan tidak ada)

Superioritas laki-laki (konteks tuo tengganai adalah orang tua atau sesepuh yg berjenis kelamin laki-laki) 
terdapat dl keluarga dg

berpedoman pd adat

20. Bekahak Istilah
Lagu kasidah yg dinyanyikan oleh sekelompok laki-laki dalam acara pesta
Superioritas laki-laki dan domestifikasi perempuan (perempuan dibatasi perannya di wilayah publik)

\section{Pembahasan}

Dalam tabel di atas, data penggunaan istilah pada budaya di kamus yang mengandung disparitas gender ditemukan 20 buah. Kosakata tersebut tersebar di wilayah Provinsi Jambi. Berikut ini pemaparan analisisnya berdasarkan penggunaan istilah pada kosakata budaya masyarakat MelayuJambi.

\section{Analisis Pengunaan Istilah}

Berikut ini analisis data kosakata pada penggunaan istilah.

- asabah; artinya 'saudara laki-laki ayah' = dominasi dan superioritas laki-laki (istilah untuk saudara perempuan Ayah dan atau dari pihak ibu tidak ada).

Istilah budaya di atas merupakan suatu bentuk realitas bagaimana posisi laki-laki dalam relasi kekerabatan difasilitasi melalui bahasa (sebutan). Melalui istilah yang mengunggulkan atau memfasilitasi satu pihak saja (dari pihak laki-laki), maka secara konstruktif, posisi ini sudah bias. Superioritas laki-laki diwacanakan dengan kemampuan mereka menciptakan sekaligus mengonstruksi bahasa yang bias gender. Dalam Kamus Kosakata Budaya Jambi, tidak ditemukan adanya padanan istilah untuk saudara perempuan ayah maupun saudara dari pihak ibu, baik laki-laki atau perempuan. Fakta ini menegaskan bahwa bahasa, terutama kosakata budaya dan lebih spesifik dalam kasus istilah di atas telah melegitimasi dominasi laki-laki di hadapan kebudayaan.

- cinge; artinya pakaian adat laki-laki berupa celana panjang terbuat dari kain beledu warna merah, bagian pinggang diberi tali, bersulam benang emas, dengan motif bunga tagapo, melati, dan pucuk rebung = detail pakaian laki-laki (dalam kamus tidak ditemukan detail serupa untuk pakaian perempuan)

Dalam persoalan pakaian, kosakata juga memainkan peran signifikan dan bahkan hegemonik. Melalui istilah yang merepresentasikan detail pakaian adat laki-laki, posisi laki-laki sudah diunggulkan dalam adat/kebudayaan. Hal ini secara harfiah lazimnya dianggap wajar karena sudah demikian adanya dalam adat. Akan tetapi, jika dilakukan pembacaan secara kritis dan relasional, maka akan terlihat hadirnya disparitas gender yang mengonstruksi dominasi lakilaki atau mengistimewakan laki-laki sebagai pihak yang diunggulkan. Kosakata yang menunjukkan padanan istilah pakaian adat untuk perempuan yang porsi dan relasinya sama dengan cinge, sejauh identifikasi di dalam kamus tidak ada. Terlihat bahwa ada kecenderungan bahasa yang bias, timpang, dan berpihak kepada salah satu posisi, yaitu laki-laki.

- datuk sutan pati; artinya sebutan untuk pohon besar yang digunakan untuk menambat jerat rusa $=$ superioritas laki-laki (metafora "datuk" sebagai kekuatan maskulin laki-laki)

Istilah di atas menarik untuk diidentifikasi disebabkan adanya konsepsi metaforik terhadap jenis kelamin laki-laki yang dilambangkan memiliki kekuatan/keperkasaan sebagaimana sifat- 
sifat alam semesta yang menunjukkan superioritasnya di hadapan manusia. Sifat-sifat tersebut kemudian diakuisisi dan seolah secara natural juga melekat (given) pada kelompok laki-laki, misalkan 'pohon besar'. Selanjutnya, konsep metafora atau simbolisasi tentang kekuatan lakilaki atau superioritas laki-laki juga terlihat jelas dari penggunaan frasa 'datuk sutan'. Dalam konteks budaya Melayu, frasa tersebut sudah secara hiperbolis menunjukkan keberpihakan yang mutlak pada laki-laki, sebab kosakata 'datuk' maupun 'sutan', tidak pernah dipakaikan sebagai sebutan bagi perempuan. Seolah sudah secara alamiah dan kodrati kata datuk dan sutan memang untuk laki-laki dengan seluruh manifestasi maskulinitasnya.

Frasa "datuk sutan" secara asosiatif dan konotatif dengan demikian menggiring pemahaman khalayak (masyarakat) kepada suatu kesimpulan bahwa yang kuat layaknya pohon besar adalah laki-laki. Pohon besar diibaratkan sebagai tubuh laki-laki yang ideal dan kuat sebab tubuh yang kuat tersebut mampu menahan tali untuk jerat rusa agar tidak kabur. Sedangkan tubuh yang kecil atau pohon yang kecil (asosiasi dari kata kecil secara implisit mengarah ke perempuan) tentu akan patah dan tidak kuat menahan tali jerat rusa. Ukuran material dan fisik ini menjadi penanda bahwa disparitas gender dalam istilah "datuk sutan pati" demikian jelas terjadi.

- duduk batanyo; artinya adat meminang, utusan keluarga pihak laki-laki berkunjung ke rumah pihak keluarga perempuan untuk menanyakan apakah anak perempuan mereka sudah ada yang punya $=$ Subordinasi perempuan (meminang seolah diasumsikan sebagai transaksi kepemilikan dari perspektif laki-laki)

Dalam istilah di atas, secara sekilas terlihat kelaziman dan tidak ada persoalan, tetapi jika konteks tersebut dikaitkan dengan arti yang dilampirkan maka terlihat terjadi disparitas gender. Konstruksi kebudayaan yang berbasis pada sistem norma seolah tidak menunjukkan hadirnya bias atau ketimpangan karena ditransmisikan secara hegemonik melalui ajaran, laku, keyakinan sehingga terkesan natural. Konteks dalam istilah "duduk batanyo" menjelaskan bahwa anak perempuan diasosiasikan sebagai "barang" atau properti yang bisa dimiliki dengan melalui serta memenuhi beberapa prasyarat adat secara kultural (transaksional).

Perempuan dalam konteks tersebut tidak memiliki hak untuk menentukan dirinya kecuali melalui perantara adat dan orang tua sehingga proses melamar menjadi sebuah proses yang berlangsung satu arah (pihak laki-laki yang memulai). Kondisi ini secara hegemonik menyatakan suatu fakta bahwa hanya kaum laki-laki yang bisa dan boleh melamar. Tujuan melamar sebagaimana dikemukakan, yaitu untuk mempunyai atau memiliki. Kata punya atau milik, memiliki, serta kepemilikan, mengarah pada hak terhadap sesuatu (benda) sebagai pemilik yang sah atau resmi. Apabila konteks dari kata "punya; milik; hak" atas sesuatu itu bersifat dominan karena sudah melalui berbagai prasyarat, maka si pemilik dengan leluasa memiliki otoritas/kuasa atas kepemilikannya tersebut. Sangat mungkin ia bisa menukar kepemilikan tersebut, menambah kepemilikan tersebut, atau bahkan menikmati kepemilikan tersebut berdasar kapasitasnya.

Uraian tersebut menjelaskan bahwa istilah "duduk batanyo" memberikan konsekuensi panjang terhadap posisi dan relasi antara perempuan dengan laki-laki dalam adat (rumah tangga, khususnya wilayah domestik). Perempuan berada dalam posisi subordinat karena sudah ditransaksikan (ada proses tukar dengan prasyarat tertentu) dan menjadi pihak yang dijadikan sebagai objek kepemilikan. Implementasi dari istilah tersebut secara konkret menghadirkan 
konsekuensi kritis bahwa perempuan adalah objek bagi sistem pranata kultural yang hegemonik sehingga terlihat hadirnya disparitas gender.

- getek; artinya lincah dan genit (terutama anak perempuan); banyak gaya = subordinasi perempuan (peyoratif)

Penggambaran atau citra terhadap perempuan dalam tradisi seolah menjadi semacam stereotipe yang tidak terbantahkan. Perempuan dengan sifat dan kekurangannya menjadi fokus perhatian kebudayaan, terutama dikaitkan dengan persoalan moral dan etika. Sifat dan citra perempuan tersebut dikontruksikan melalui bahasa-bahasa yang secara minor serta inferior yang bertujuan membentuk hegemoni terhadap sifat perempuan di hadapan publik. Tujuan dari pola konstruktif dan hegemonik tersebut adalah menciptakan citra perempuan ideal sesuai selera patriarki. Bahasa pada kesempatan yang sama secara konstruktif dan ideologis, berupaya mengakuisisi realitas dengan menawarkan representasi terhadap sifat dan stereotipe perempuan.

Melalui bahasa yang kontruktif tersebut, istilah bagi perempuan memiliki asosiasi minor bahkan peyoratif. Kata "getek" diartikan sebagai perempuan yang lincah, genit, banyak gaya. Kelakuan dan sikap perempuan dalam kata getek tersebut mengarah pada aktivitas yang berlebihan (polah dan tingkah lakunya). Pemakaian atau penggunaan kata tersebut ke sosok perempuan seolah melegitimasi suatu selera konstruktif kaum laki-laki, bahwa perempuan yang baik adalah perempuan yang diam, pemalu, tidak banyak gaya, sedangkan perempuan yang "kurang" baik adalah perempuan yang getek tersebut. Ada nilai yang secara peyoratif mendiskreditkan perempuan di hadapan publik (kebudayaan) melalui perilaku getek tersebut sehingga perempuan mengalami subordinasi dan objektivikasi. Dalam Kamus Kosakata Budaya Jambi tidak ditemukan padanan istilah untuk laki-laki yang merepresentasikan sifat yang serupa, karena tidak hanya perempuan yang banyak gaya, laki-laki pun bisa jadi ada.

- jok; artinya panggilan untuk laki-laki muda yang masih bujangan = diskriminasi (panggilan serupa untuk perempuan muda tidak ada)

Konteks dari kosakata di atas menunjukkan bentuk diskriminasi yang terjadi antara posisi lakilaki dan perempuan di dalam kebudayaan Jambi dengan hanya memfasilitasi salah satu pihak saja. Terjadi praktik diskriminasi dalam bahasa lokal atau daerah Jambi yang merepresentasikan sebuah angan-angan atau gagasan terhadap posisi gender sehingga laki-laki diberikan porsi (ada) dalam sistem kebudayaan. Kehadiran istilah tersebut mewacanakan bahwa bahasa untuk mendeskripsikan laki-laki dalam kosakata budaya Jambi memiliki sistematika yang deskriptif (informasi yang detail) sesuai tingkatan usia subjek yang dibahas.

- kulub/kulup; artinya 1) panggilan untuk anak yg belum dikhitan;2) panggilan sayang untuk orang yg sudah dewasa $=$ diskriminasi (konteks panggilan untuk laki-laki)

Sebagaimana kasus istilah sebelumnya, kata "kulub/kulup" ini juga merepresentasikan bagaimana bahasa untuk laki-laki lebih dominan, memiliki detail-detail bentuk dalam konteks tertentu. Hal ini sangat berbeda jika disandingkan dengan bahasa yang merepresentasikan (wilayah) perempuan, terlihat sangat timpang dan tidak semua kosakata untuk perempuan secara adil dan deskriptif memberikan ruang bagi subjektivitisnya.

- Lacak; artinya bagian pakaian adat laki-laki, sejenis tutup kepala terbuat dari kain beledu berwarna merah bersulam benang emas, bermotif daun, tangkai, dan bunga, bagian depan 
berbentuk runcing ke atas dan bagian belakang datar = superioritas laki-laki (pakaian dengan fungsi serupa yang dikenakan untuk perempuan tidak disebutkan dalam kamus)

Detail aksesoris pakaian adat juga tidak luput dalam praktik yang menghadirkan bias gender. Melalui bahasa yang digunakan, praktik disparitas bisa terjadi ketika bahasa cenderung memfasilitasi salah satu pihak, misalkan memiliki atau menghadirkan istilah untuk detail pakaian laki-laki yang mana posisi istilah tersebut tidak ditemukan padanannya dalam aksesoris atau detail pakaian adat perempuan. Bagian pakaian yang disebutkan tersebut secara konstruktif dan hegemonik menunjukkan superioritas laki-laki di hadapan kebudayaan. Terlihat dari detail, deskripsi, dan makna "lacak" yang mengarah pada kewibawaan sosok lakilaki di dalam kebudayaan secara patriarkat.

- lenjeh; artinya lincah dan genit (terutama anak perempuan); banyak gaya; getek $=$ subordinasi perempuan (peyoratif)

Kata "lenjeh" di atas, secara harfiah memiliki makna yang sama dengan kata "getek" yang sudah diuraikan pada analisis sebelumnya. Penggunaan istilah tersebut hanya berlaku pada perempuan (dikenakan pada perempuan) yang memiliki perilaku atau sikap yang berlebihan di dalam kebudayaan. Citra yang dilekatkan terhadap perempuan dengan perilaku "lenjeh" tersebut mengimplikasikan hal yang peyoratif sebab di mata kebudayaan (patriarkat) konstruksi terhadap sosok perempuan yang baik harus kalem, tenang, sopan, dan tidak banyak tingkah.

- mangku; artinya 1) pemimpin dusun yang berperan sebagai sekretaris dan wakil penghulu; 2) pemimpin adat yang berada di bawah Depati $(\mathrm{Kubu})=$ superioritas dan dominasi laki-laki (pemimpin).

Dalam sistem sosial masyarakat Melayu Jambi, keberadaan laki-laki masih menjadi pusat dalam hierarki kebudayaan. Hal tersebut ditunjukkan melalui posisi laki-laki yang menjadi pemimpin serta istilah dalam kosakata budaya yang turut melegitimasinya. Istilah mangku dalam sistem sosial (adat) masyarakat diperuntukkan kepada seorang laki-laki dan bukan kepada perempuan karena dianggap laki-laki lebih cakap dalam memimpin. Konstruksi yang hegemonik ini menghadirkan suatu realita bahwa dalam suatu kebudayaan, laki-laki selalu menjadi ukuran untuk menentukan suatu putusan. Laki-laki diasumsikan cenderung rasional sedangkan perempuan cenderung emosional. Sebagai seorang pemimpin (yang dituntut adil), rasio menjadi prasyarat mutlak. Perempuan secara sosial belum diberikan kesempatan dalam adat dan tradisi untuk muncul di sektor publik serta menjadi pemimpin bagi kelompoknya.

- nambang; artinya menjual diri untuk memenuhi kebutuhan ekonomi = objektivikasi perempuan

Tubuh dalam kebudayaan adalah suatu konstruksi politis dan ekonomis. Dalam konteks istilah di atas, posisi tubuh dilihat sebagai medium transaksional (alat tukar) di hadapan kepentingan dan aktivitas kebudayaan, baik itu personal maupun komunal. Tubuh dengan demikian adalah aset yang mampu memberikan akses ke wilayah-wilayah yang selama ini sangat mendasar, yaitu persoalan materi. Melalui istilah tersebut, posisi tubuh (terutama tubuh perempuan) secara material dikomodifikasi sebagai barang yang dipertukarkan sehingga tubuh perempuan yang dilabeli dengan istilah "nambang" hanya menjadi objek bagi suatu sistem sosial yang lebih besar, yaitu hasrat. Menjual diri dengan demikian memosisikan tubuh sebagai aktivitas 
konsumsi yang pada akhirnya tidak memberikan penghargaan terhadap hak-hak privat perempuan sebagai manusia seutuhnya.

- pakcik; artinya kata sapaan yang digunakan untuk menyapa saudara laki-laki ayah dan ibu yang berperawakan kecil

- pakmuk; artinya kata sapaan yang digunakan untuk menyapa saudara laki-laki ayah dan ibu yang berperawakan gemuk

- pakte; artinya kata sapaan yang digunakan untuk menyapa saudara laki-laki ayah dan ibu yang berkulit putih

$=$ tiga istilah di atas menunjukkan superioritas dan dominasi laki-laki (untuk perempuan tidak disebutkan)

Tiga istilah di atas memperlihatkan gejala dari keberpihakan bahasa yang secara dominan memprioritaskan laki-laki pada posisi yang diunggulkan. Kata sapaan yang diperuntukkan kepada laki-laki dari pihak orang tua dan tidak ditemukan istilah bagi perempuan dengan konteks yang sama. Fakta tersebut dengan jelas melegitimasi bahwa laki-laki dalam kebudayaan adalah makhluk yang istimewa terutama sekali kebutuhan akan bahasa untuk sebutan/menyebut seorang laki-laki. Berbeda halnya dengan perempuan, istilah atau bahasa untuk mereka sangat terbatas dan dibatasi.

- putri kandis; artinya kue yang terbuat dari 20 butir telur, air pandan, tepung, gula, margarin, yang dimasak dengan cara dipanggang lapis demi lapis = objektivikasi perempuan dan stereotipe terhadap perempuan melalui istilah "putri” (perempuan) sebagai makanan.

Hal yang menarik dalam kasus di atas adalah terjadinya proses asosiasi terhadap perempuan melalui pertautannya dengan makanan. Seolah ada hubungan yang erat antara makanan dengan perempuan. Asosiasi ini secara kultural merupakan sebuah konstruksi mental yang digerakkan oleh gagasan bahwa (rasa) makanan memiliki sifat yang sama dengan (rasa) perempuan. Homologi atau kesejajaran ini merupakan sudut pandang yang mengobjektivikasi perempuan dari sudut pandang patriarkat bahwa perempuan sebagaimana halnya makanan memiliki sifatsifat yang untuk dikonsumsi. Berdasarkan kondisi tersebut, penamaan "putri kandis" sebagai salah satu kue tradisional Jambi menjadi sangat ideologis jika dihubungkan dengan persoalan gender. Orientasi tersebut akan terus menjadi wacana yang direproduksi kultur patriarki sebagai suatu bentuk objektivikasi terhadap perempuan.

- sundai; artinya kekuatan gaib yang dilakukan dengan membaca mantra atau guna-guna untuk memikat perempuan $=$ objektivikasi perempuan (mantra untuk memikat laki-laki tidak ada/tidak disebutkan)

Dalam aktivitas kebudayaan pun juga terjadi praktik yang memperlakukan perempuan sebagai objek dan sasaran dengan tujuan untuk memiliki atau memperdaya seorang perempuan melalui bantuan kekuatan gaib. Perempuan dipikat karena kebudayaan (patriarki) selalu mewacanakan secara turun-temurun bahwa perempuan adalah pelengkap, bagian dari kebutuhan hidup lakilaki, prestise di hadapan sistem sosial kultural. Laki-laki yang tidak beristri atau belum beristri diasumsikan inferior dan belum lengkap. Melalui kenyataan yang demikian perempuan menjadi subordinat dan laki-laki ordinat di hadapan kebudayaan. Terlebih lagi dalam konteks istilah sundai di atas, posisi laki-laki yang dominan tersebut semakin melegitimasi bahwa perempuan adalah objek bagi hasrat dan ambisi kaum laki-laki. 
- sundang; artinya senjata genggam tradisional yang terbuat dari besi yang ditempa pipih, mempunyai dua mata yang berbentuk meruncing ke ujung, tangkai terbuat dari kayu yang berbentuk kepala burung berparuh panjang, berfungsi sebagai pelengkap pakaian dalam upacara adat dan dipakai oleh hulu balang = superioritas dan dominasi laki-laki (konteks hulu balang adalah mereka yang berjenis kelamin laki-laki)

Senjata termasuk properti dalam kebudayaan tradisional di masyarakat nusantara. Senjata dalam konteks kebudayaan identik dengan kaum laki-laki sekaligus menawarkan prestise yang menghubungkannya sebagai wibawa. Penamaan suatu jenis senjata bisa mengacu pada kemampuan dan fungsi dari senjata tersebut maupun simbolitas terhadap yang sakral. Kondisi yang demikian menegaskan bahwa senjata cenderung mengarah kepada maskulinitas laki-laki, keperkasaan, kekuatan, hingga penanda kelas sosial dalam suatu kebudayaan.

Dalam konteks istilah di atas, sundang menegaskan bahwa senjata memang diperuntukkan untuk hulubalang, yang secara jenis kelamin adalah laki-laki. Fungsi senjata tersebut secara implisit adalah membantu dalam melakukan aktivitas atau pekerjaan yang berisiko dengan keselamatan. Aktivitas yang berisiko memerlukan alat/senjata sebagai pertahanan diri. Dalam kebudayaan tradisional secara umum, hanya laki-laki saja yang dipandang mampu melakukan berbagai aktivitas yang berisiko, termasuk memiliki dan menggunakan senjata untuk keperluan membela diri. Kaum perempuan diposisikan tidak mampu melakukan aktivitas tersebut sehingga terlihat superioritas dan dominasi dari laki-laki.

- Tengganai; artinya saudara laki-laki

- Tuo tengganai; artinya saudara laki-laki dari pihak istri dan pihak suami dalama sekumpulan keluarga yang bertugas mengarahkan dan menyelesaikan masalah yang terdapat dalam keluarga dengan berpedoman pada adat

= superioritas laki-laki (konteks tuo tengganai adalah orang tua atau sesepuh yang berjenis kelamin laki-laki)

Pengertian dan konteks dari tuo tengganai dalam kebudayaan Melayu mengarah pada hadirnya suatu aturan tidak tertulis (konstruksi sosial) yang secara hierarkis disepakati bersama tentang pemilihan orang (laki-laki) yang dianggap lebih mumpuni atau memiliki kapasitas dalam keluarga (baik kapasitas berpikir, perilaku, maupun kapasitas pengalaman hidup). Laki-laki yang dewasa (tua), matang, dan memiliki kecakapan atau pandangan pemikiran dengan demikian akan selalu dilibatkan karena diasumsikan memiliki kebijaksanaan.

Perspektif terhadap wacana kebijaksanaan dalam istilah tuo tengganai tersebut tentu saja sudah merupakan suatu wujud superioritas laki-laki. Dalam gagasan filsafat yang cenderung patriarkis, superioritas laki-laki ini seolah-olah berpijak pada rasio/nalar (logos), sedangkan perempuan diasumsikan berpijak pada emosi/rasa (mitos). Konstruksi ini yang secara turuntemurun mendominasi realitas kebudayaan secara hegemonik. Konsep logos dan mitos seolaholah menjadi semacam kenyataan yang alamiah. Termasuk di dalamnya adalah penggunaan bahasa yang cenderung konstruktif, yang bertujuan mencapai suatu gagasan baik secara simbolik maupun eksplisit.

- bekahak; artinya lagu kasidah yang dinyanyikan oleh sekelompok laki-laki dalam acara pesta = superioritas dan domestifikasi perempuan (di ruang publik perempuan dibatasi aksesnya). 
Dalam kasus istilah "bekahak" di atas, perempuan mengalami domestifikasi sehingga untuk kegiataan kebudayaan (seni dan hiburan) yang muncul adalah laki-laki. Keberadaan perempuan dalam kegiatan hiburan diasumsikan akan mendatangkan godaan atau kecenderungan maksiat (dosa) sehingga untuk mencegah kondisi yang tidak diinginkan tersebut, laki-laki yang diberi ruang. Secara religius, kasidah adalah salah satu seni dari kebudayaan Islam. Konteks tersebut secara jelas memengaruhi cara pandang terhadap perempuan dan juga relasi yang terjadi di dalam hubungan antara laki-laki dengan perempuan. Bisa disimpulkan bahwa dalam pertunjukan bekahak tersebut, perempuan menempati posisi subordinat sebagai akibat domestifikasi yang membatasi aktivitas mereka.

\section{Simpulan dan Saran Simpulan}

Secara umum dari data sumber Kamus Kosakata Budaya (2015) menunjukkan bahwa istilah kosakata budaya yang berkembang dan digunakan mengandung unsur disparitas gender. Data penggunaan istilah yang mengandung unsur disparitas gender ditemukan 20 buah dan istilah tersebut masih digunakan dalam proses komunikasi masyarakat Melayu Jambi. Relasi antara perempuan dengan laki-laki secara sosial kultural dalam adat dan tradisi secara signifikan memang mengalami banyak negosiasi, terutama dalam kaitannya dengan gender. Dalam dimensi tersebut, bahasa (kosakata budaya) menjadi jejak yang menandai bahwa disparitas gender masih terjadi, bahkan terus dikonstruksikan ulang sebagai suatu sistem yang dianggap wajar. Hal inilah yang ditemukan dalam penggunaan istilah pada budaya masyarakat Melayu Jambi, bahwa praktik berkebudayaan secara signifikan turut memberikan kontribusi terhadap hadirnya disparitas gender melalui bentuk-bentuk istilah. Penelitian ini sekaligus berupaya melengkapi kemungkinankemungkinan munculnya sebaran kosakata yang belum dimasukkan melalui jenis lain selain istilah.

\section{Saran}

Penelitian ini dapat dilanjutkan dengan meninjau pada penggunaan variasi lain selain penggunaan istilah mungkin bisa dilihat dari variasi peribahasa, kiasan atau yang lainnya. Kosakata budaya dalam Kamus Kosakata Budaya Jambi menunjukkan bahwa di beberapa (bahkan mayoritas) wilayah kabupaten yang ada di Provinsi Jambi secara umum memiliki karakteristik terjadinya gejala disparitas gender dalam bahasa dan kebudayaannya. Melalui asumsi tersebut, sangat mungkin untuk ditemukan fenomena-fenomena kebudayaan yang memiliki kecenderungan bias gender, termasuk di dalamnya penggunaan bahasa.

\section{Daftar Pustaka}

Adriana, Iswah. 2012. Bahasa dan Gender: Antara Dominasi dan Subordinasi (Sebuah Kajian Sosiolinguistik).Jurnal Okara, II Tahun 7.

Faraz, Nahiyah Jaidi. 2013. Makalah Penelitian Perspektif Gender. Yogyakarta: Fakultas Ekonomi, Universitas Negeri Yogyakarta.

Fakih, Mansour 2013. Analisis Gender \& Transformasi Sosial. Yogyakarta : Pustaka Pelajar 
Gin, Ooi Keat (Ed.). 2004. Southeast Asia: A historical encyclopedia, from Angkor Wat to East Timor. Santa Barbara, California: ABC Clio.

Huda, Nuril, Aliyah A. Rasyid, Pujiati Suyata, dan Sumarno. 2013. Pengembangan Model Penelitian Perspektif Gender.Jurnal Penelitian dan Evaluasi Pendidikan, Tahun 17 Nomor 2.

Kamus Kosakata Budaya Jambi yang disusun oleh Kantor Bahasa Jambi edisi kedua (2015).

Katubi. 2004. Studi Bahasa dan Jender: Sejarah Singkat, Ancangan, dan Model Analisis. Jurnal Masyarakat dan Budaya, Vol.VI(1).

Muhajir, Noeng. 1990. Metodologi Penelitian Kualitatif. Yogyakarta: Rake Sarasin.

Mulia, Siti Musdah. 2004. Islam Menggugat Poligami. Jakarta: Gramedia Pustaka Utama. (Cetakan I).

Showalter, Elaine (Ed.). 1983. Speaking of Gender. New York \& London: Routledge.

Wibowo, Prasetyo Adi Wisnu. 2012. Bahasa dan Gender. Jurnal Lite, Vol. 8(1). 